\title{
Poultry housing in the Arab World: Applying principles of thermal exchange to improve performance (A case study of Morocco)
}

\author{
Ahachad, M. ${ }^{1}$, R. Belarbi ${ }^{2}$, N. Bouaziz ${ }^{3}$, A. Draoui ${ }^{1}$ and F. Allard ${ }^{2}$ \\ ${ }^{1}$ Faculty of Sciences and Techniques B.P. 416 Tangier Morocco. ${ }^{2}$ LEPTAB University of \\ La Rochelle, France ${ }^{\mathfrak{c}}$ Institut Préparatoire aux Etudes d'Ingénieur d'Elmanar, Tunis, \\ Tunisia
}

\begin{abstract}
The design, siting and orientation of many modern poultry houses in Arab countries indicate that the principles of thermal exchange are not widely known or, if known, are too often ignored. In this paper the measures which could be used to reduce the fatal effect of the heat stress phenomenon are presented by modelling and simulating a typical poultry house. A case study was conducted to show the influence of each parameter on the behaviour of the building. The most influential parameters are: ventilation, shape, orientation, number of occupants etc. The evaporative cooling systems models were linked to thermal building software, TRNSYS, and the assessment of a poultry house equipped with passive cooling systems will be presented. The simulations show that the heat stress phenomenon could be avoided. The experimental study of the poultry house equipped with a passive cooling system shows a decrease of the internal air temperature (up to $9{ }^{\circ} \mathrm{C}$ ), and an improvement of the production quality, which is shown by a decrease in mortality rate and an increase in body weight.
\end{abstract}

Keyword: Poultry housing, passive cooling, heat stress, TRNSYS, Arab World.

$$
\begin{aligned}
& \text { عنابر الدواجن في العالم العربي تطبيق مبادئ التبادل الحراري لتحسين الأداء (دراسة } \\
& \text { حالة في المغرب) مبادئ) } \\
& \text { م. أحشاد1 ؛ ر. بلعربي؛ ن. بوعزيز³ ع. الدراوي؛؛ ف. ألار2 } \\
& \text { 1كلية العلوم والتقتيات ص.ب. } 416 \text { طنجه، المغرب جامعة لاغوشيل LEPTAB فرنسا، 3المعهد التحضيري للاراسات } \\
& \text { الهندسية المنار تونس } \\
& \text { الملخص: تنم طريقة إنثاء البنايات الحديثة المخصصة لتربية الدواجن في العالم العربي، وكذا موقعها وتوجيهها، عن عدم } \\
& \text { معرفة مبادئ التبادل الحراري بشكل كاف، أو أن هذه المبادئ ينم تجاهلها رغم معرفتها. وسنتناول في هذا المقال الإجر اءات } \\
& \text { التي يمكن اتخاذها لخفض التأثير الضار لظاهرة التوتر والقلق الناجم عن الحرارة ، وذللك عن طريق النمذجة والمحاكاة } \\
& \text { المعلوماتية لبناية مثالية لتربية الدواجن. لقد أجرينا در اسة لحالة معينة لبيان تأثثر كل عامل من العوامل على سلوك البناية. } \\
& \text { و العو امل الأكثر تأثثرا هي: التهوية و الثكل و التوجيه و عدد الدواجن داخل البناية ....الخ. لقد تمت الدراسة الحر ارية للبنايات }
\end{aligned}
$$

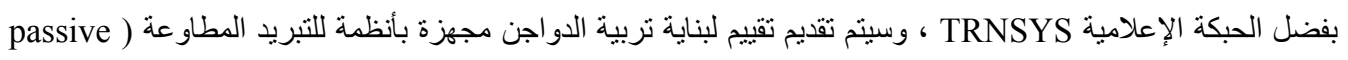

$$
\begin{aligned}
& \text { cooling ) . تثبت عمليات الدحاكاة إمكانية تلافي ظاهرة التوتر والقلق الناجم عن الحرارة. تبين الدراسة التجريبية التي } \\
& \text { أجريت على بناية لتربية الدو اجن مجهزة بنظام للتبريد المطاوع انخفاضا للحر ارة الداخلية (تصل إلى } 9 \text { درجات) وتحسنا في } \\
& \text { جودة الإنتاج تتضح من خلال تراجع عدد الوفيات وزيادة وزن الدواجن. } \\
& \text { الكلمات المفتاحية: عنابر الدواجن، التبريد السلبي، انتقال الحرارة، TRNSYS ، العالم العربي }
\end{aligned}
$$




\section{Introduction}

The purpose of a poultry house is to confine the birds; to protect them from predators and environmental extremes which would cause mortality or reduced growth, feed efficiency, immunocompetence, fertility or egg production; to facilitate light control; and to facilitate bird management. Expected temperature and humidity extremes are important factors that influence poultry house design. Prolonged periods with daily maximum temperatures over $42{ }^{\circ} \mathrm{C}$ make it very difficult (if not impossible) to achieve good flock performance with naturally ventilated housing. Highhumidity environments reduce the effectiveness of evaporative cooling ( $\mathrm{R}$. A. Ernst). The quality of poultry production is then conditioned by a perfect command of the environment in the poultry house. In Arab countries, where outside temperature can reach $41^{\circ} \mathrm{C}$, poultry are subjected to severe stress and they cannot be sustained for long periods of time under these conditions without evaporative cooled housing. During the 2003 summer, losses due to excessive heat in Morocco were estimated at about ten million Euros (FISA). In other hot weather Arab countries, a large number of poultry farmers do not grow birds in summer owing to the high mortality rate Alloui $\mathrm{N}$, et al. Nevertheless, this is not a problem specific to hot countries. In France, bird losses from improper environment are estimated at six million Euros per year Bouvarel., et al.

The strategies put forward to reduce the negative effects of heat will depend on the type of thermal stress to which birds are exposed. In the case of heat stress, the solutions are essentially technical (amelioration of poultry houses and adaptation of farming techniques). In the case of prolonged or chronic exposures, nutrition or genetic solutions can be considered so as to ameliorate the birds' growth.

Although drops in production due to thermal stress anorexia may be partly prevented by compensatory adjustment of the ration, suitably designed housing is necessary to reduce the environmental heat load to which birds may be exposed and to secure optimum conditions for their heat dissipation. The design, siting and orientation of many modern poultry houses in Arab countries indicate that the principles of thermal exchange are not sufficiently widely known or, if known, are too often ignored.

This paper attempts to assist with the problem by presenting practical recommendations based on elementary principles of thermal exchange and relevant bio meteorological knowledge.

The aim of this work is to master the environment in poultry houses in the Arab World. To achieve this, we had first to diagnose the dynamic behaviour of the poultry house in order to suggest solutions that are well adapted to existing houses, and to finally find a method of cooling that would reduce the temperature in the houses with minimum energy consumption.

For the case study of Morocco, we used the TRNSYS computer program for the modelling and simulation of the energy flows of the poultry house of Tangier (North of Morocco). Experimental evaluations were realised on two identical poultry houses: one is equipped with a system of passive cooling and the other one is not equipped.

\section{Poultry farming in the Arab World}

The poultry industry in Arab countries has expanded remarkably in recent years. According to 2003 statistics (Table 1), the private investments in this sector are estimated at about 8 billion US\$ (FAO).

In Jordan, for example, the total investments in the poultry industry are estimated at US\$ 430 million at both the 
private and public levels. The numbers of broiler farms has increased substantially since 1981 through 2000 and the production capacity of each farm has also improved (Table 2). Consumption of poultry meat has also increased in a similar manner over the same period (Table 3). The egg industry has also grown and developed rapidly in the past few years. There are now about 275 poultry farms specializing in egg production with a total housing capacity of about 6.0 million birds (Table 4) (Salah and Esmail, 2003).

In Morocco, the poultry sector has known a remarkable development since the beginning of the 1970s. The production of white meat increased from 57000 tons in 1975 ( $3.25 \mathrm{~kg} /$ person per year ) to 255000 tons in $2001 \quad(9.10$ $\mathrm{kg} /$ person per year), among which 200000 tons coming from the industry sector; which is an average growth rate of $13 \%$ a year (which corresponds to an average growth per capita of about $7 \%$ a year). This progress is related to the development of the private sector of industry in which the rhythm of progress was stronger during the last five years. The observed progress is the result of incentive measures that allowed the sector to respond promptly to the market's needs. The white meat position of the total meat consumption increased from $23 \%$ in 1970 to $45 \%$ in 2001 Guedira A., et al. As for the production of eggs for consumption, eggs increased from 400 millions units in 1975 to 3.3 billions in 2001, an annual average increase of $27 \%$. Consumption eggs represent 2.4 billion units of the total industry production.

However, despite improvements in poultry production in almost all the Arab countries during the last decades, poultry farming is always facing constraints of different types. It should be emphasized that the individual consumption of poultry remains below the nutritional standards recommended or admitted by the international specialised organisations such as FAO, and WHO, and a deficit in animal protein is always registered Sbihi A. et al. It is accepted that in order to increase the daily animal protein consumption per capita, consumption of poultry products should be augmented. It is thus important to contribute to the development of this sector, and to improve poultry production by surmounting the most difficult problem of heat stress.

\section{Principles of thermal exchange to improve performance: a case study of Morocco}

\section{TRNSYS program overview}

TRNSYS is a transient systems simulation program with a modular structure and is used in the present study for deriving the results. Each module contains a mathematical model for a system component. The TRNSYS engine calls the system components based on the input file and iterates at each time-step until the system of equations is solved.

For the present study, TRNSYS Type 56 is used to model the thermal behaviour of a typical poultry house in Tangier. All heating and cooling loads arising from walls, windows, flat roof and floor are calculated with Type 56 model, by utilising the transfer function method (Klein et al., 1998). This method simplifies calculations and can provide the instantaneous heat flux entering or leaving a zone through the various parts of the building.

The evaporative cooling systems were developed and coupled to the TRNSYS environment.

Weather data are needed to perform the simulation with TRNSYS. Because of the non availability of the meteorological data of the city of Tangier, a calculation was realised by using the hourly solar global irradiance on horizontal surface, ambient temperature, humidity, wind speed and direction for 2001 and 2002. 
Table 1. Private investments in poultry industry in Arab countries (million US \$).

\begin{tabular}{lcc}
\hline & $\begin{array}{c}\text { Private investments in poultry industry in Arab } \\
\text { countries (million US \$) }\end{array}$ \\
\cline { 2 - 3 } Country & Year 2003 & Year 2010 (expected) \\
\hline Algeria & 793 & 1049 \\
Comoros Islands & 2 & 3 \\
Egypt & 1734 & 2194 \\
Libya & 332 & 443 \\
Mauritania & 18 & 25 \\
Morocco & 974 & 1268 \\
Sudan & 119 & 162 \\
Tunisia & 316 & 412 \\
Bahrain & 16 & 20 \\
West Bank and Gaza & 254 & 336 \\
Iraq & 160 & 506 \\
Jordan & 357 & 455 \\
Kuwait & 129 & 163 \\
Lebanon & 418 & 446 \\
Oman & 20 & 25 \\
Qatar & 15 & 18 \\
Saudi Arabia & 1472 & 2835 \\
Syria & 466 & 570 \\
United Arab Emirates & 98 & 122 \\
Yemen & 267 & 381 \\
Total Arab countries & 7960 & 10432 \\
\hline - Source: FAO & &
\end{tabular}

* Source: FAO

Table 2. Development of poultry meat production in Jordan from 1981 through 2000.

\begin{tabular}{cccc}
\hline Year & No. of farms & $\begin{array}{c}\text { Total production capacity } \\
(\mathbf{1 0 0 0} \text { tons of poultry meat) }\end{array}$ & $\begin{array}{c}\text { Actual production } \\
(\mathbf{1 0 0 0} \text { tonnes })\end{array}$ \\
\hline 1981 & 870 & 32.0 & 29.5 \\
1985 & 1326 & 69.0 & 55.0 \\
1990 & 1448 & 81.0 & 50.0 \\
1995 & 2125 & 128.4 & 107.0 \\
1996 & 2156 & 134.0 & 100.0 \\
1997 & 2161 & 135.0 & 102.0 \\
1998 & 2168 & 135.0 & 104.5 \\
1999 & 2181 & 139.0 & 107.2 \\
2000 & 2185 & 142.0 & 108.0 \\
\hline
\end{tabular}


Emir. J. Food Agric. 2008. 20 (1): 60-75

http://www.cfa.uaeu.ac.ae/research/ejfa.htm

Table 3. Consumption of poultry meat from 1981 through 2000.

\begin{tabular}{ccc}
\hline Year & $\begin{array}{c}\text { Total consumption } \\
(\mathbf{1 0 0 0} \text { tonnes })\end{array}$ & $\mathbf{k g} /$ person year \\
\hline 1981 & 34.8 & 13.0 \\
1985 & 56.5 & 21.0 \\
1990 & 63.4 & 19.7 \\
1995 & 100.0 & 23.8 \\
1996 & 107.0 & 25.0 \\
1997 & 108.0 & 26.0 \\
1998 & 111.0 & 28.0 \\
1999 & 111.5 & 28.5 \\
2000 & 114 & 30.5 \\
\hline
\end{tabular}

Table 4. Production, consumption and exports of eggs from 1981 through 2000.

\begin{tabular}{cccccc}
\hline Year & No. of farms & $\begin{array}{c}\text { Total egg production } \\
\text { (million) }\end{array}$ & $\begin{array}{c}\text { Total egg cons. } \\
\text { (million) }\end{array}$ & Egg/person/year & $\begin{array}{c}\text { Exports } \\
\text { (million) }\end{array}$ \\
\hline 1981 & 188 & 340 & 277 & 121 & 63 \\
1985 & 149 & 520 & 387 & 145 & 133 \\
1990 & 200 & 530 & 496 & 159 & 34 \\
1995 & 257 & 715 & 712 & 169 & 3 \\
1996 & 266 & 726 & 723 & 172 & 3 \\
1997 & 268 & 727 & 723 & 170 & 4 \\
1998 & 271 & 730 & 723 & 170 & 7 \\
1999 & 272 & 730 & 724 & 172 & 6 \\
2000 & 275 & 732 & 724 & 171 & 8 \\
\hline
\end{tabular}

\section{Model poultry house construction}

For the estimation carried out in this paper, a typical model poultry house was considered as illustrated in figure 1. It is oriented towards the North direction. It has a floor area of $500 \mathrm{~m}^{2}$ and consists of four identical externals walls: $50 \mathrm{~m}$ in length and $4 \mathrm{~m}$ in height for the north and south walls with a total window opening of $16.5 \mathrm{~m}^{2}$ on each wall, and $10 \mathrm{~m}$ in length and $4 \mathrm{~m}$ in height for the east and west walls with a total window opening of $3 \mathrm{~m}^{2}$ on each wall. The overall heattransfer coefficient of the walls is $\mathrm{U}=$ $0.842 \mathrm{w} / \mathrm{m}^{2} . \mathrm{k}$.

The compared buildings are labelled as:

Type 1: no roof insulation ( $U=2.233$ $\left.\mathrm{w} / \mathrm{m}^{2} . \mathrm{k}\right)$ poultry house.

Type 2: $25 \mathrm{~mm}$ roof insulation $(\mathrm{U}=$ $0.691 \mathrm{w} / \mathrm{m}^{2} . \mathrm{k}$ ) poultry house.

Both buildings are constructed from double walls $(0.07 \mathrm{~m}$ hollow brick, 0.02 $m$ cement coating on each side and an interior air space) and flat roof $(0.07 \mathrm{~m}$ hollow brick, $0.1 \mathrm{~m}$ concrete and a 0.02 $\mathrm{m}$ cement coating). The farming capacity of both buildings is 10000 broilers.

The internal gains in temperature due to the occupants and to the light are assessed to $90 \mathrm{~W} / \mathrm{m}^{2}$ during the occupied period. With windows open during summer, the infiltration airflow rate is assumed to be constant and equal to ten air change per hour Dimoudi A.

\section{Results and Discussion}

Simulations were realized on the typical building during summery periods, by using meteorological data measured on the site where the building is implanted. A case study was realized to show the influence of each parameter on the behaviour of the building. The most influential parameters are: ventilation, 
shape, orientation, number of the occupants etc.... The assessment of a poultry house equipped with passive cooling systems is shown below.

\section{Effect of ventilation}

The effect of introducing naturally or mechanically ambient air into the space when the outdoor air is of a lower temperature than the indoor one during the summer is investigated.

The simulation shows that, in summer, the higher the ventilation rate, the lower the indoor temperature for a non conditioned poultry house (Figure 2). The effect of ventilation rate on the reduction of the maximum indoor temperature for poultry house with no roof insulation is shown more clearly in (Figure 3). It can be seen that without ventilation (be it natural or mechanical), the indoor temperature will reach $45^{\circ} \mathrm{C}$. With ventilation, this temperature will decrease by about $1.5^{\circ} \mathrm{C}$ per 2 air changes per hour, $2.7^{\circ} \mathrm{C}$ for 5 air changes per hour and $3.8^{\circ} \mathrm{C}$ for 10 air changes per hour. In the summer due to the thermal storage effect of the building envelope, and due to the important number of poultry inside the poultry house, there may be a requirement to extract heat from the building in order to maintain it at about $28{ }^{\circ} \mathrm{C}$, which represents the temperature of comfort during the last two weeks of rearing in which the chickens are very sensitive to the heat. Therefore a reduction of the cooling load may be obtained if the ventilation rate is increased (naturally or mechanically), to take advantage of the lower temperature of the outside air.

The simulation results are presented in (Figure 4), and show that a reduction of the cooling load is obtained, when the air changes per hour increase. The effects of ventilation on the cooling load for the no roof and roof insulation constructions are presented in table 5. As it is seen, when maintaining the poultry house at $28{ }^{\circ} \mathrm{C}$ in summer, the ventilation leads to a maximum reduction of cycle cooling load of $29.9 \%$. The reduction of cooling load increases with insulation.

\section{$\underline{\text { Figure captions }}$}

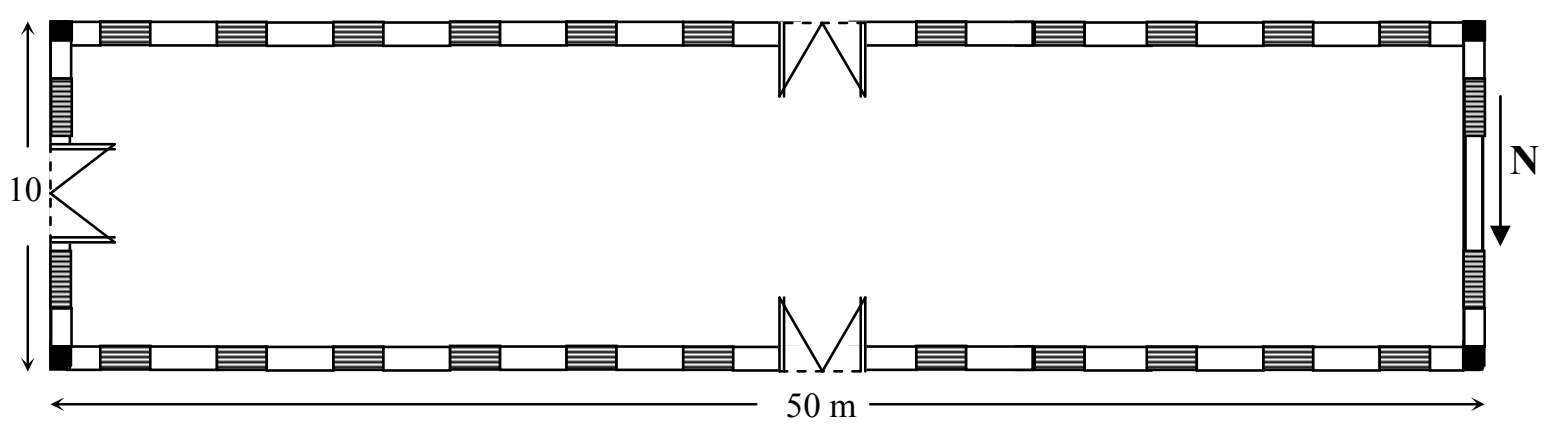

Plan view

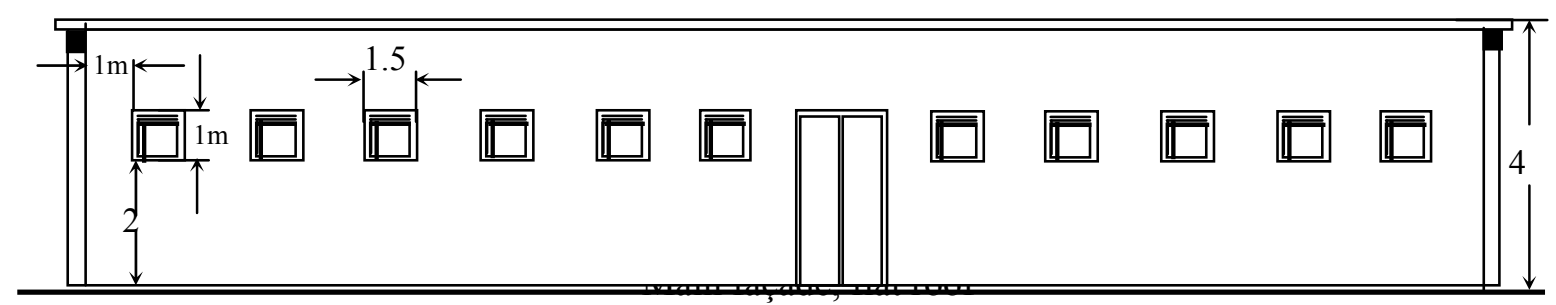

Figure 1. Model poultry house (Shape 1). 
Emir. J. Food Agric. 2008. 20 (1): 60-75

http://www.cfa.uaeu.ac.ae/research/ejfa.htm

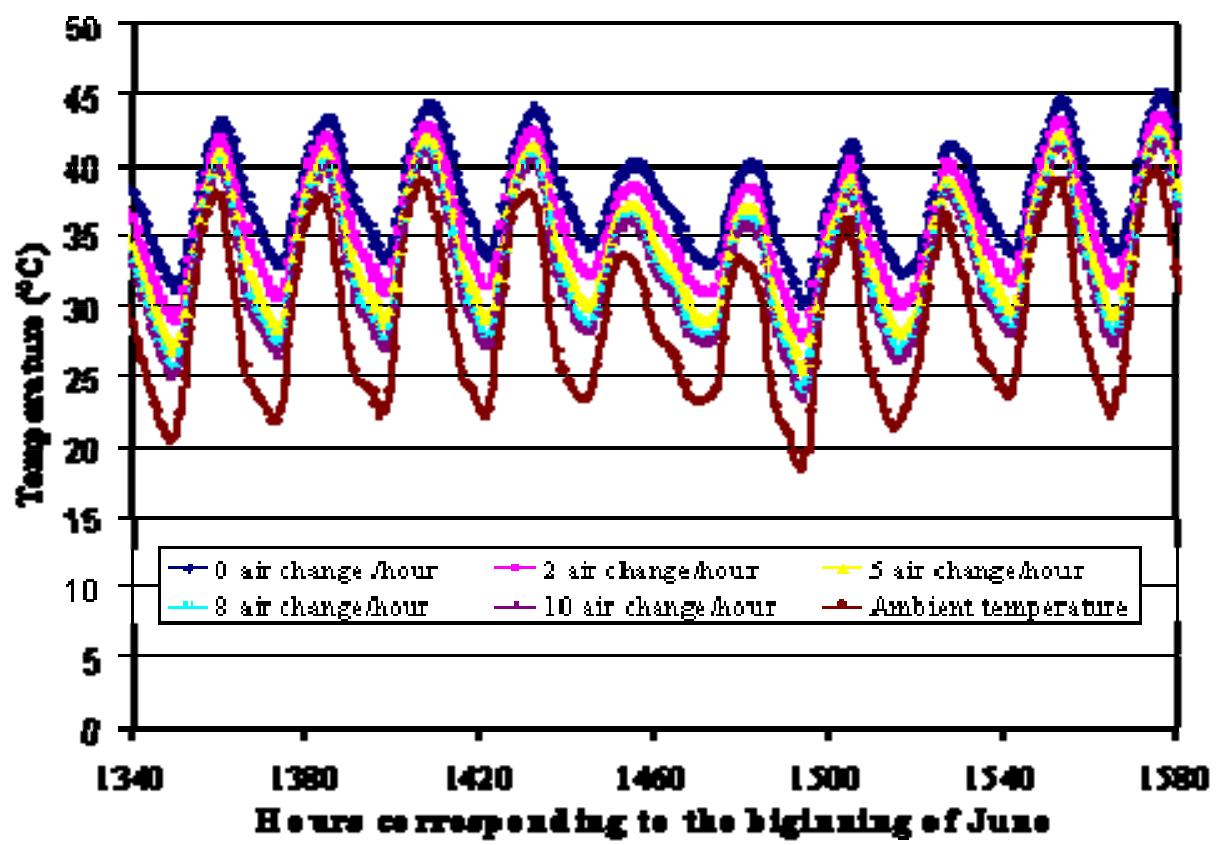

Figure 2. Temperature variation of a typical poultry house with no roof insulation indicating the effect of ventilation during the beginning of June.

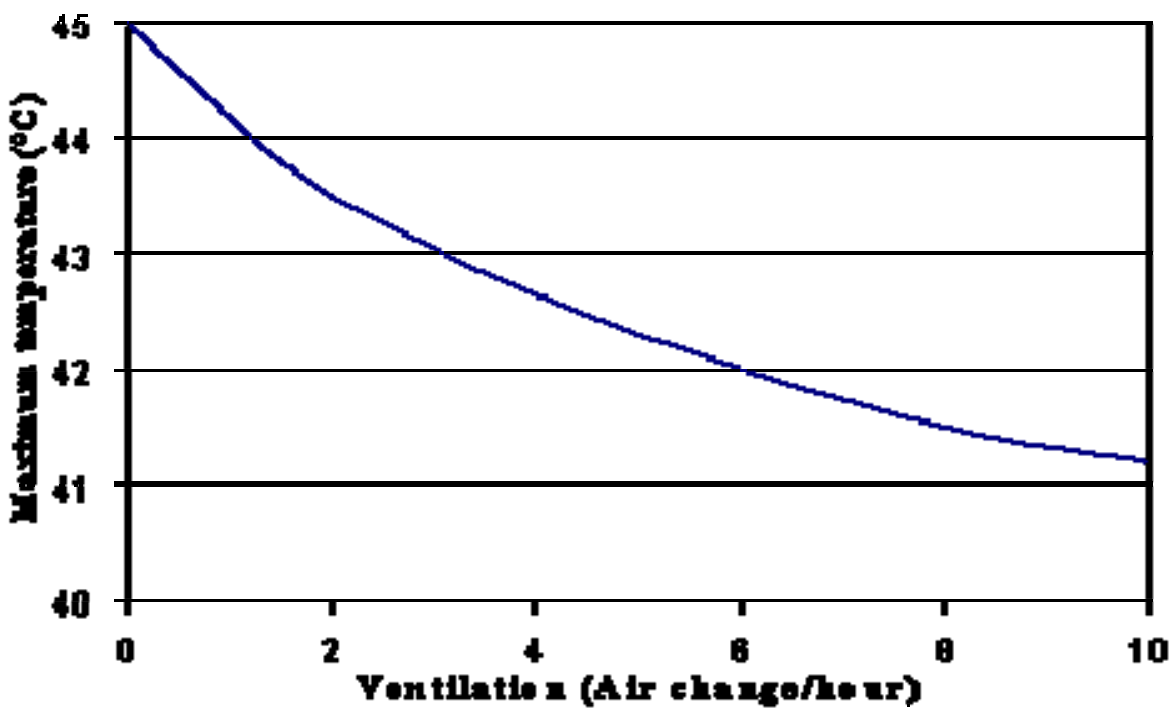

Figure 3. Ventilation effect on the maximum indoor temperature for a typical poultry house. 


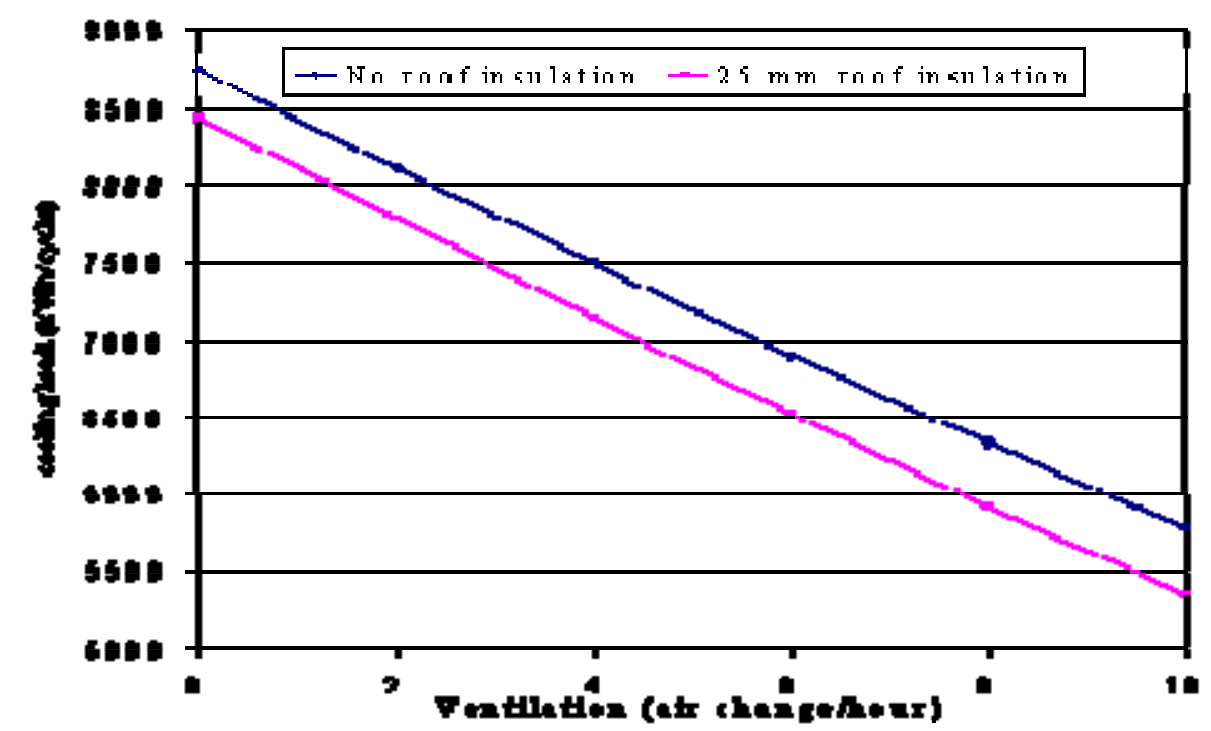

Figure 4. Effect of ventilation on the cooling load per cycle for maintaining.

Table 5. Cooling load for various roof constructions indicating the effect of ventilation.

\begin{tabular}{ccccc}
\hline $\begin{array}{c}\text { Air changes } \\
\text { per hour }\end{array}$ & $\begin{array}{c}\text { No-roof } \\
\text { Cooling load } \\
(\mathbf{k W h} / \mathbf{c y c l e})\end{array}$ & $\begin{array}{c}\text { Insulation } \\
\text { Load reduction } \\
\mathbf{( \% )}\end{array}$ & $\begin{array}{c}\mathbf{2 5} \mathbf{~ m m ~ r o o f} \\
\text { Cooling load } \\
\mathbf{( k W h / c y c l e )}\end{array}$ & $\begin{array}{c}\text { Insulation } \\
\text { Load reduction } \\
\mathbf{( \% )}\end{array}$ \\
\hline 0 & 8744 & -- & 8435 & -- \\
2 & 8111 & 7.2 & 7784 & 7.7 \\
4 & 7497 & 14.3 & 7145 & 15.3 \\
6 & 6901 & 21.0 & 6519 & 22.7 \\
8 & 6330 & 27.6 & 5914 & 29.9 \\
\hline
\end{tabular}

Effect of poultry house shape and orientation

The exposed surface area of the building is related to the rate at which the building gains or loses heat while the volume is related to the ability of the building to store heat. Thus, the ratio of volume to exposed surface area is widely used as an indicator of the rate at which the building will heat up during the day and cool down at night. A high volumeto-surface ratio is preferable for a building that is desired to heat up slowly, as it offers small exposed surface for the control of both heat losses and gains Balaras C.
In order to examine the effect of the shape and orientation of the poultry house, a new model house plan that will decrease the wall area while keeping the same volume is necessary. This model, named shape 2, is illustrated in (Figure 5). Shape 2 has double the width and half the length of the original model house resulting in a wall perimeter of $90 \mathrm{~m}$ instead of $120 \mathrm{~m}$ of the original model.

Table 6 presents the cooling load variation between the houses with different shapes. For this analysis, the previous two construction types were examined for every shape. The results show that the rectangular shape 2 model exhibits a significant decrease in the 
cooling load of between 8.2 and $11.3 \%$ in respect to the elongated model house shape 1, depending on the construction type. Therefore the results show that a smaller area-to-volume ratio is preferable.

To examine the effect of orientation for the climate conditions encountered in Tangier, Morocco, the four models are rotated from their present orientation, in a clock-wise direction through $180^{\circ}$. Figure 6 shows the cooling load difference presented by the four models for different orientations.

Shape 1 shows the minimum cooling load per cycle at no rotation because at this position the east wall area, which has the biggest load contribution, is minimised.

Shape 2 also shows the minimum cooling load per cycle with no rotation. The decrease of the cooling load difference (at 90 degrees compared to 45 degree) is logical because this shape is almost symmetrical. For both shapes, with different constructions, the initial position is the best one from the thermal point of view. However, it is best to use narrower houses in hotter climates. With floor housing, 10-11 m (32.8-36.1ft) widths are popular in very hot climates (Ernst R. A.).
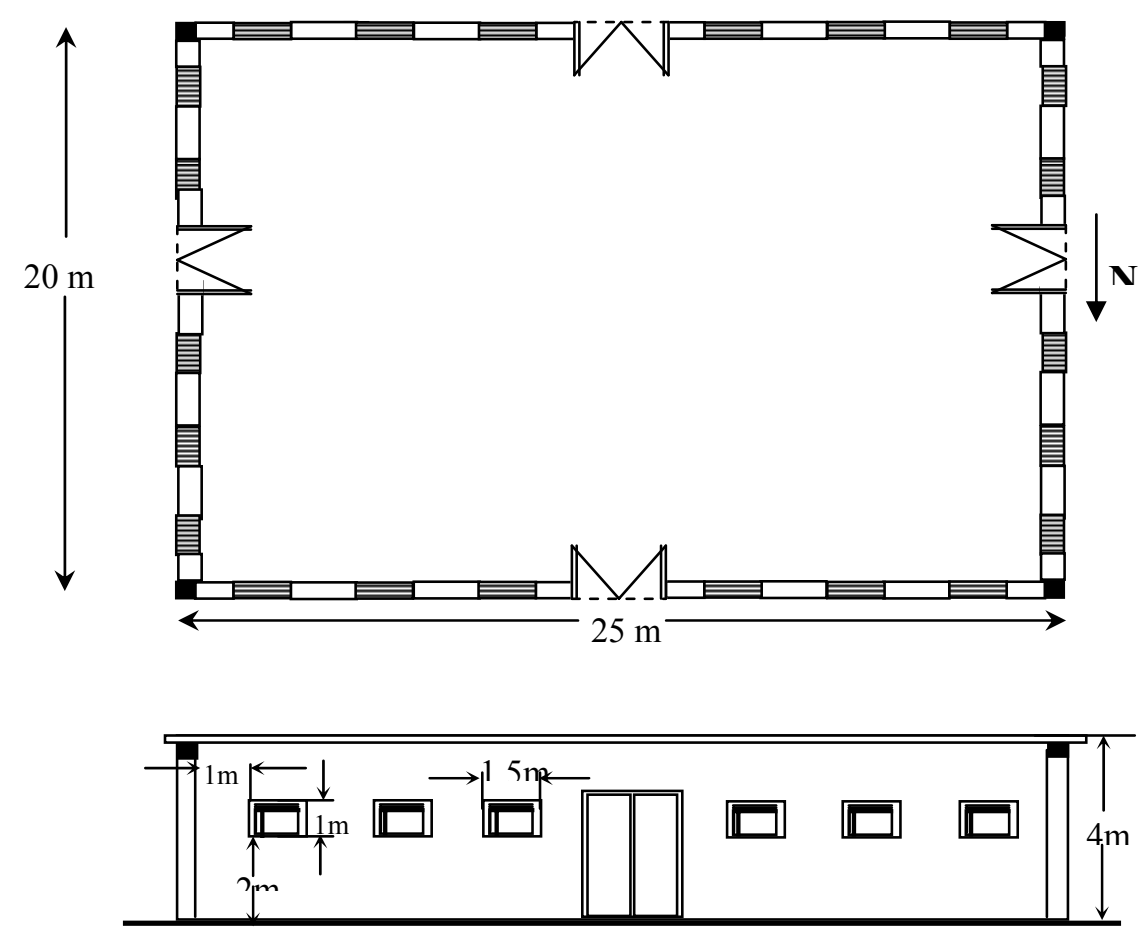

Main facade, flat roof

Figure 5. Model poultry house (Shape 2); with changed dimensions but with the same floor area and volume.

Table 6. Cooling load variation per cycle between buildings of different shapes in summer.

\begin{tabular}{|c|c|c|c|c|}
\hline \multirow{2}{*}{ Case } & \multirow{2}{*}{ Model farming } & \multicolumn{2}{|c|}{ Cooling load per band (kWh) } & \multirow{2}{*}{\begin{tabular}{|c|} 
Percentage difference \\
compared to shape $1(\%)$
\end{tabular}} \\
\hline & & Shape 1 & Shape 2 & \\
\hline Type 1 & No roof insulation & 8744 & 7756 & 11.3 \\
\hline Type 2 & $25 \mathrm{~mm}$ roof insulation & 8435 & 7740 & 8.2 \\
\hline
\end{tabular}




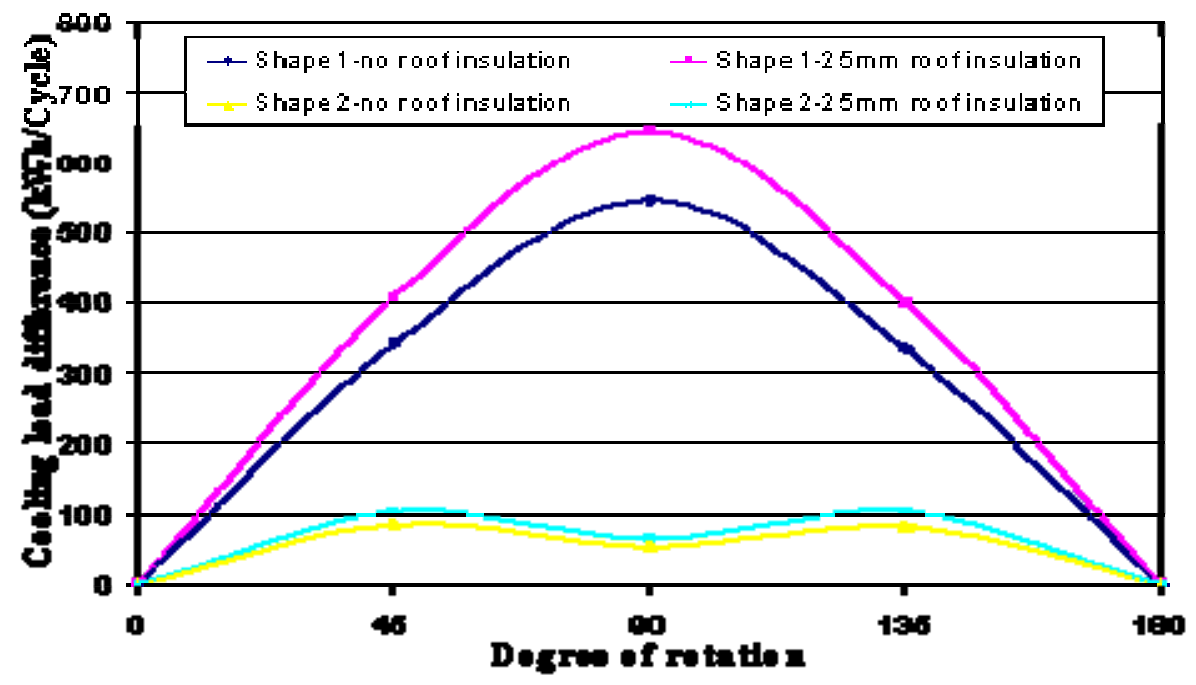

Figure 6. Cooling load different against degree of rotation of the models.

\section{Effect of inclined roof}

The effect of constructing an inclined roof instead of the traditional flat roof is examined. As is illustrated in (Table 7) the inclined roof results in a decrease of load between 3.9 and $14.4 \%$ depending on its orientation and time of summer, when constructed in the same way as the flat roof.

\section{Effect of poultry house coating.}

The solar absorbance coefficient depends on the properties of the wall finish. (Table 8) illustrates the effect of poultry house coating on the cooling load.

\section{Effect of poultry number}

Finally, the effect of the poultry number is examined. The occupants (chickens) emit, by basic metabolism and by physical activity, a considerable quantity of heat in the building. They therefore represent a measurable source of energy. Their contribution is translated by superheating of the atmosphere and by a supplementary need for cold. (Table 9) shows the percentage of the cooling load decrease when the number of the occupants are decreased.

\section{Assessment of building equipped with passive cooling systems}

The results of the simulation on the present poultry house highlight the necessity to refresh the building in order to avoid the heat stress phenomenon. The installation of a classical air conditioning system to meet this need will notably abate the interior air temperature. However, this remains beyond the reach of the poultry farmers of the region because of the high costs of both the energy and the installation.

The evaporative system is preferred for cooling because of its simplicity, effectiveness and low energy consumption. Thus the necessity to develop and then to couple the numerical models of these systems behaviour towards the thermal models of the house in order to evaluate the gain achieved following the use of these techniques. The numerical models have been presented in detail in a previous work Belarbi R., et al. 2001. (Figure 7) gives the flow diagram of the TRNSYS deck file.

\section{Description of the studied evaporative system}

The behaviour of the poultry house cooled by two evaporative systems, the evaporative cooling pad and the high- 
pressure fog cooling system, are described.

- Evaporative pad cooling.

The most important element of this cooling system is the pad that allows the water evaporation. This component consists of a specially formulated cellulose paper, impregnated with insoluble anti-rot salts, stiffening saturants and wetting agents. The pad is illustrated in (Figure 8). In such a system, an adiabatic process takes place resulting in cooling and humidifying the air. The use of this system is recommended in very low humidity areas. The pads have a cross-fluted configuration that provides maximum cooling when warm air passes through the wet pad material.

According to Allard and Belarbi model (Allard F and Belarbi R.) the performance of such a system depends on the size of the wetted surface, thermal and physical conditions of the inlet air and the moisture of the system surface. Experimental and numerical studies of direct evaporative cooling systems (Belarbi R., 1998) show that the efficiency value is in the range of 0.5 to 0.8 . It is defined by the following relationship:

$$
\varepsilon_{\text {cooling }}^{\text {Pad }}=1-\exp \left(-\frac{k A_{\text {eff }}}{m_{a}^{\prime}}\right),
$$

where,

$\mathrm{k}$ : Mass transfer coefficient (air-vapor) $\left(\mathrm{kg} \mathrm{m}^{-2} \mathrm{~s}^{-1}\right)$

$A_{\text {eff }}$ : Effective exchange surface (wetted media-air) of the pad $\left(\mathrm{m}^{2}\right)$

$m_{\mathrm{a}}$ : Mass airflow $\left(\mathrm{kg} \mathrm{s}^{-1}\right)$

For a unity pad cooling surface $(\mathrm{A}=1$ $\mathrm{m}^{2}$ ), electrical consumption of the system does not exceed 0.05 Watt for a unit airflow rate $\left(11 \mathrm{~s}^{-1}\right)$, and the consumption of water does not exceed 0.41 day and by unit airflow rate $\left(11 \mathrm{~s} \mathrm{~s}^{-1}\right)$ (Erens, 1988).

A pump allows a water supply, contained in a tank, to the pad system. The fans installed on the opposite side create a depression and absorb air through the pad. The contact of air with the wet surfaces of the cellulose leads to a liquid evaporation (latent heat of evaporation) and thus to a cooling in the poultry house.

- High-pressure fog cooling.

This system (Figure 9) consists of a pump feeding the forging tubing and the atomizing nozzles assembled on the tubing, which atomizes pressurized water. As water evaporates (latent heat of evaporation $=2500 \mathrm{~kJ} / \mathrm{kg}$ of water), the surrounding air is cooled and humidified.

In regards to the high pressure fog system, by knowing the flow rate delivered by the atomizing and the rate of evaporation, the number of the atomizing nozzles to be installed can be estimated to fill the needs of cooling of the poultry house.

For the poultry houses studied in Tangier, by assuring 10 air changes per hour, the house should be provided with a tubing of 72 nozzles of $6 \mathrm{l} / \mathrm{h}$ to substitute an ordinary cooling system of maximal power equal to $300 \mathrm{kw}$.

\section{Simulation results.}

The results indicate that the use of the passive cooling system can avert the production misfortunes due to heat stress that often strikes at the end of the cycle, when the internal temperature gains (due to the occupants) are maximised. A decrease of the maximum temperature from $45{ }^{\circ} \mathrm{C}$ to $32.2{ }^{\circ} \mathrm{C}$ has been observed (Figure 10) in the case of pad cooling and to $30.7^{\circ} \mathrm{C}$ in the case of high pressure fog cooling system.

\section{Experimental evaluation of a poultry house equipped with high-pressure fog cooling system.}

The two identical poultry houses $(82$ x $11.65 \times 3 \mathrm{~m}^{3}$ ) considered for this study are situated $12 \mathrm{~km}$ away from Tangier. In these buildings, heat stress has frequently caused flagrant mortality. They are oriented towards the Northeast direction and have a floor area of $955.3 \mathrm{~m}^{2}$. The 
number of poultry in each house was 8000 broilers.

One of the two poultry houses is equipped with the high pressure fog cooling system (only on the Southeast facade) in order to study the influence of the passive cooling system on the mortality and on the quality of production. The high-pressure fog system consists of 83 nozzles of $61 / \mathrm{hr}$ of atomized water at high pressure (70 bars). Because of the lack of reliable electricity, the system was fed by a generator. This technical constraint obliged us to use the system only when the inside temperature exceeds $35^{\circ} \mathrm{C}$.

During the warm days, the installation led to a decrease in the internal temperature (down to $9{ }^{\circ} \mathrm{C}$ ). Concerning the quality of production, a decrease in percentage mortality rate and an increase of the poultry weight was recorded.

The passive cooling system could also be used for disinfectation and for odor abatement along with cooling.

The experimental results are summarized in (Table 10).

The losses of this poultry farmer for July were estimated at 2400 Euro, which is equivalent to the third of the price of the installation. Consequently, the amortization of the installation can be made in three or four flocks, which is a very good payback.

Table 7. Cycle cooling loads $(\mathrm{kWh} / \mathrm{cycle})$ at $28^{\circ} \mathrm{C}$ for flat and inclined roof for different shapes.

\begin{tabular}{lcccccc}
\hline Case & Flat roof & $\begin{array}{c}\text { Inclined } \\
\text { roof } \\
\mathbf{1 5}^{\circ} \mathbf{~ N - S}\end{array}$ & $\begin{array}{c}\text { \% cooling } \\
\text { load } \\
\text { decrease }\end{array}$ & $\begin{array}{c}\text { Inclined } \\
\text { roof } \\
\mathbf{1 5}^{\circ} \mathbf{~ E - W}\end{array}$ & $\begin{array}{c}\text { \% cooling } \\
\text { load } \\
\text { decrease }\end{array}$ \\
\hline Shape 1 & Type 1 & 8744 & 7540 & 13.7 & 7559 & 13.5 \\
& Type 2 & 8435 & 7219 & 14.4 & 7222 & 14.4 \\
Shape 2 & Type 1 & 7756 & 7435 & 4.1 & 7454 & 3.9 \\
& Type 2 & 7740 & 7160 & 7.5 & 7164 & 7.4 \\
\hline
\end{tabular}

Table 8. Cooling load variation per cycle between buildings of different coating.

\begin{tabular}{ccc}
\hline Coating & $\begin{array}{c}\text { Cooling load } \\
(\mathbf{k W h} / \mathbf{c y c l e})\end{array}$ & $\begin{array}{c}\text { Percentage difference in } \\
\text { respect to shape 1 (\%) }\end{array}$ \\
\hline Model poultry house & 8744 & -- \\
Medium dark color & 8157 & 6.7 \\
Medium bright color & 7574 & 13.4 \\
White color & 6796 & 22.3 \\
\hline
\end{tabular}

Table 9. Effect of the poultry number on the cooling load.

\begin{tabular}{ccc}
\hline Number of poultries & $\begin{array}{c}\text { Cooling load } \\
\text { (kWh/cycle) }\end{array}$ & $\begin{array}{c}\text { \% cooling } \\
\text { load decrease }\end{array}$ \\
\hline 10000 & 8744 & -- \\
9000 & 8099 & 7.4 \\
8000 & 7466 & 14.6 \\
7000 & 6852 & 21.6 \\
5000 & 5685 & 34.9 \\
\hline
\end{tabular}


Emir. J. Food Agric. 2008. 20 (1): 60-75

http://www.cfa.uaeu.ac.ae/research/ejfa.htm

Table 10. Experimental results.

\begin{tabular}{lcc}
\hline Technical results & $\begin{array}{c}\text { Poultry house } \\
\text { without passive }\end{array}$ & $\begin{array}{c}\text { Poultry house with passive } \\
\text { cooling system }\end{array}$ \\
\hline Date of entrance & 14 July 2003 & 15 July 2003 \\
Number of poultries for farming & 8000 & 8000 \\
Date of sale & 22 August 2003 & 24 August 2003 \\
Number of sold poultries & 6995 & 7446 \\
Total weight at the sale $(\mathrm{kg})$ & 13012.8 & 14743.08 \\
Individual sharp weight $(\mathrm{kg})$ & 1.860 & 1.980 \\
Mortality (number) & 1005 & 554 \\
Mortality rate (\%) & 0.125 & 0.069 \\
Total weight of consummate food $(\mathrm{kg})$ & 26450 & 29635 \\
Consumption rating & 3.78 & 3.98 \\
\hline
\end{tabular}

the poultry house at $28^{\circ} \mathrm{C}$.

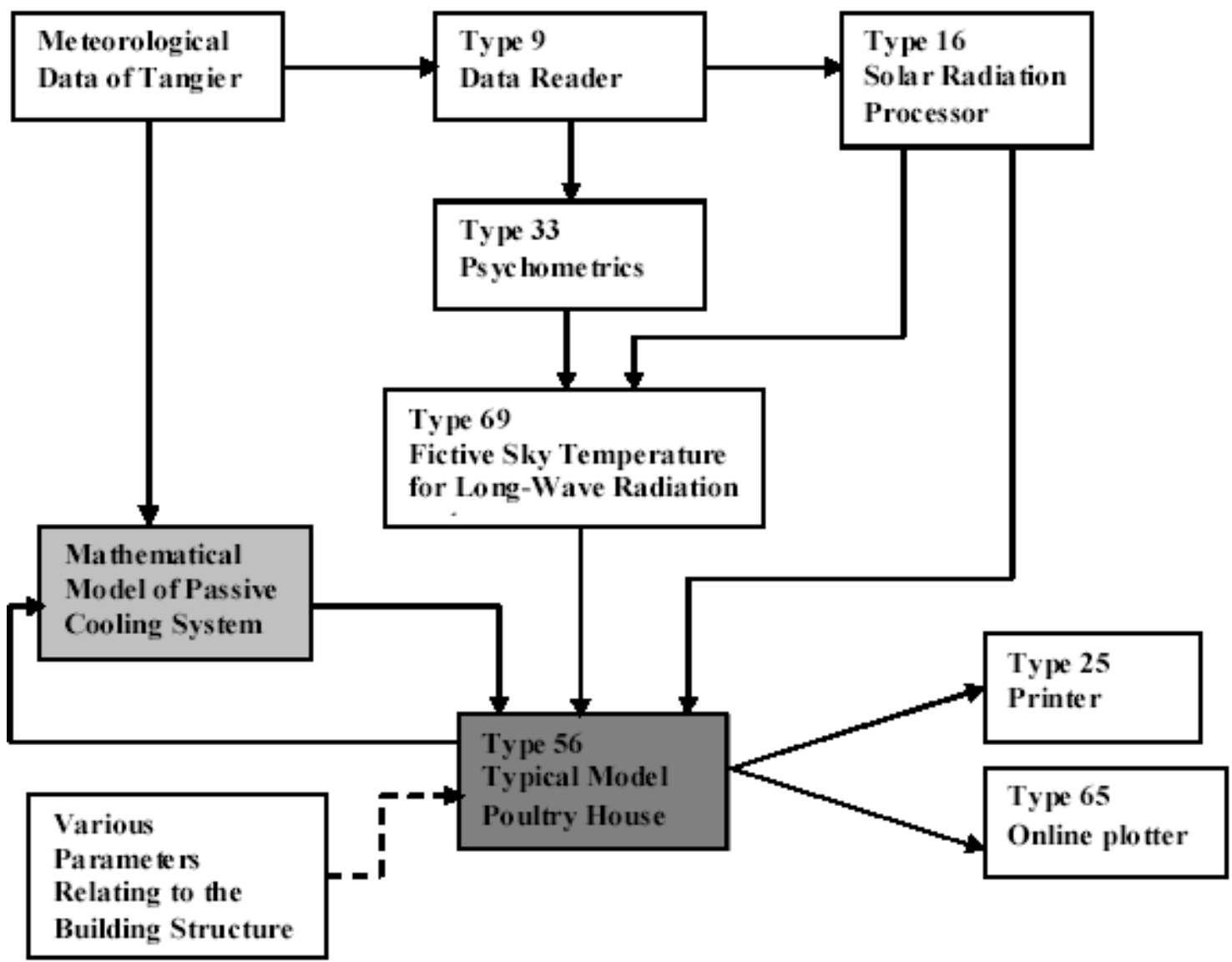

Figure 7. Flow diagram of the TRNSYS deck file. 
M. Ahchad et al.

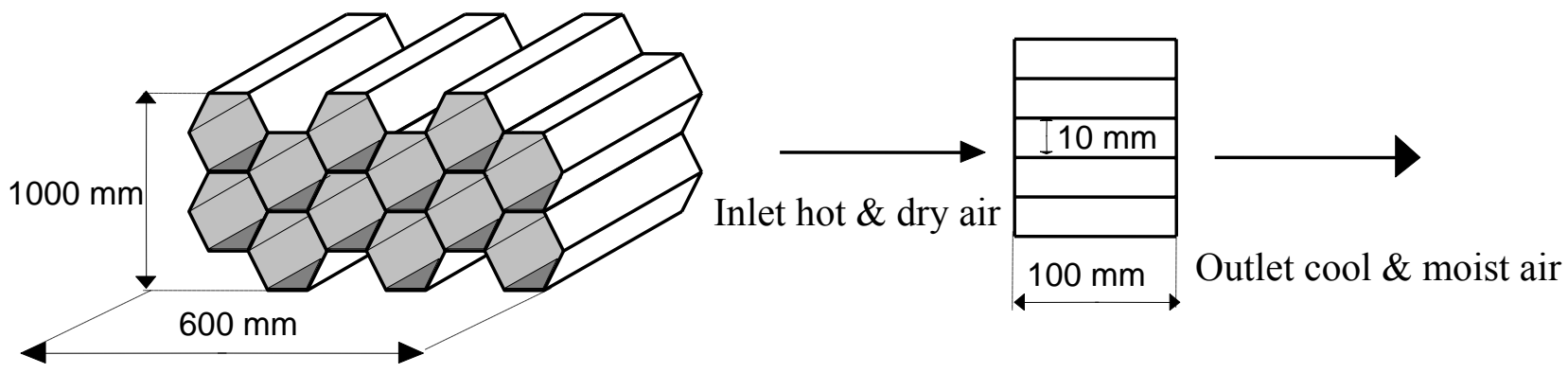

Figure 8. Pad cooling diagram.

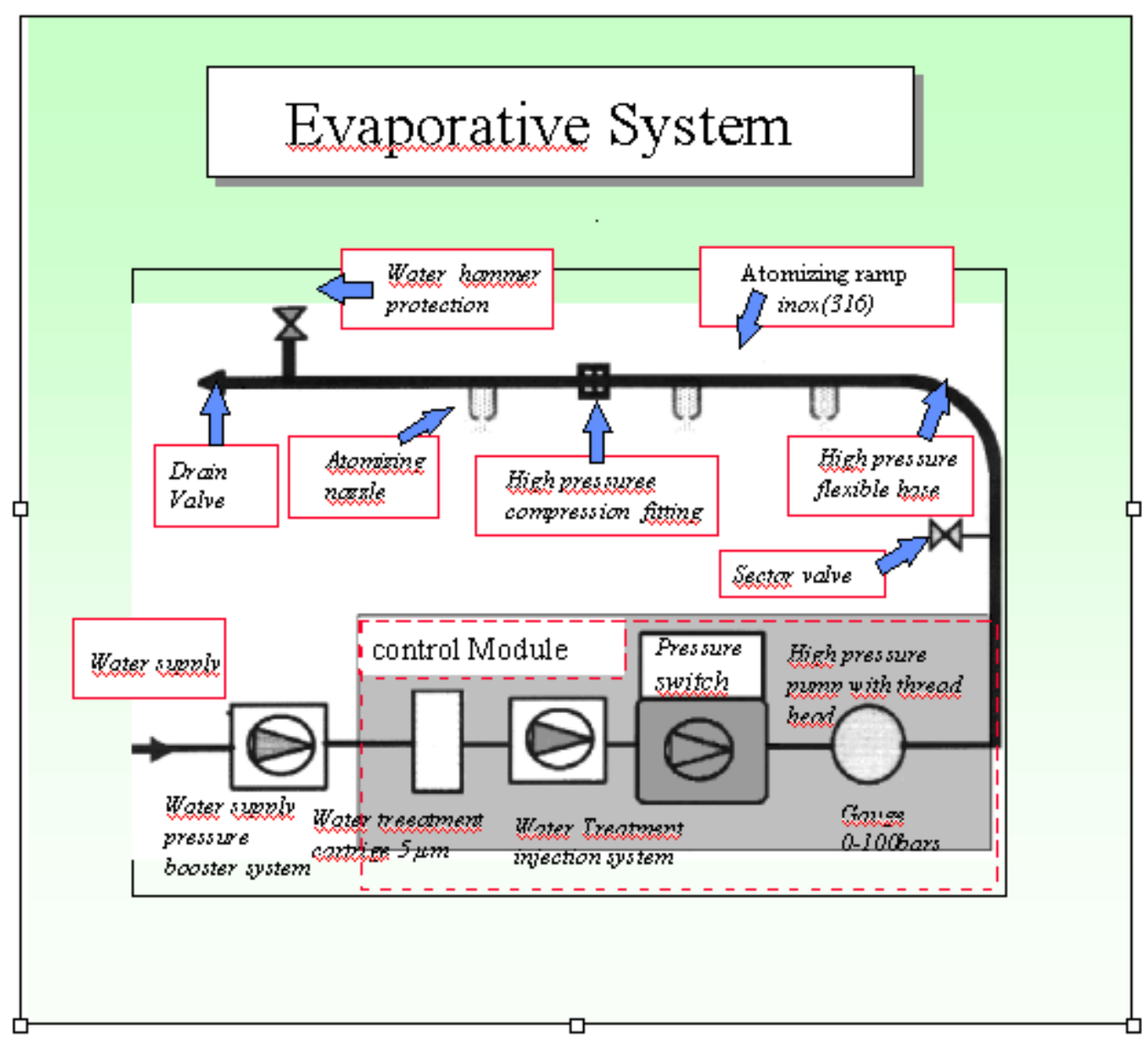

Figure 9. High pressure fog cooling system. 


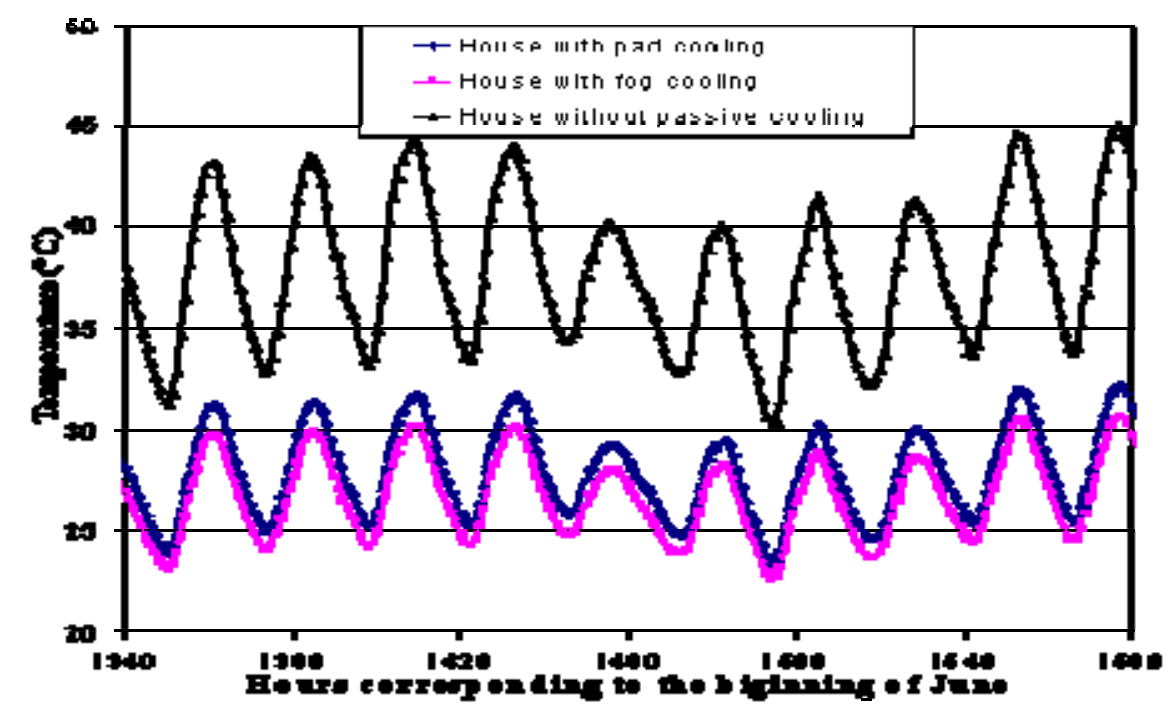

Figure 10. Simulation results of poultry house equipped with Pad cooling and high pressure fog cooling system.

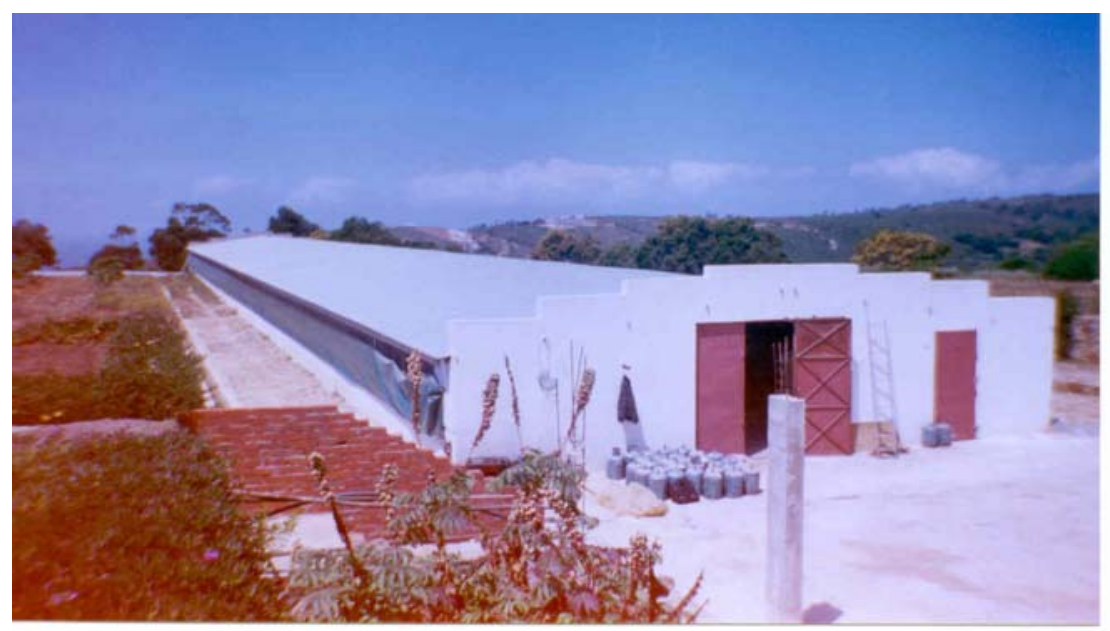

Figure 11. Poultry house equipped with High-pressure fog cooling system.

\section{Conclusion}

The measures that can be used to reduce the fatal effect of the heat stress phenomenon were investigated. This has been performed by modelling and simulating a typical poultry house. The simulations have allowed us to see the effects of various parameters on the thermal behaviour, and on the energy consumption of the poultry house. The most influential parameters are: ventilation, shape, orientation, the number of the occupants, etc. These simulations also show the necessity to urgently refresh the building in order to avoid the heat stress phenomenon. The evaporative systems were chosen because of their simplicity, their effectiveness and their low energy consumption.

Having linked the models of cooling systems to the thermal building software, TRNSYS, we have studied the interaction between poultry house type, climatic conditions and cooling system. The results show a decrease of the maximum temperature from $45^{\circ} \mathrm{C}$ to $32.2^{\circ} \mathrm{C}$ in the case of the Pad-cooling, and to $30.7^{\circ} \mathrm{C}$ in the case of the high pressure fog cooling system. This has encouraged us to undertake an experimental study on two 
identical poultry houses: one equipped with a system of passive cooling and the other one was not. The aim of these experiments was to show, on the one hand, the performance of the high pressure fog cooling system for meeting the poultry house cooling loads, and on the other hand, the main advantages of using such a system. Thus, a decrease of the internal temperature of about $9^{\circ} \mathrm{C}$ was noticed. As regarding the quality of production, an important decrease in the mortality rate together with an increase in the poultry weight was noticed.

\section{Acknowledgements}

The authors wish to acknowledge financial support of the C. I. H. E. A. M. and technical support of B.R.O. Micro Mist.

\section{References}

Allard, F. and R. Belarbi. .1998. Metodologia de evaluacion de las tecnicas pasivas de enfriamiento. COTEDI'98. Caracas.

Alloui, N. and A. Tlidjene. 2001. Effet de l'optimisation de quelques paramètres de l'ambiance des poulaillers sur les résultats zootechniques en été. Journée de la recherche avicole. 4:45-48.

Balaras, C. 1997. Cooling in buildings. In: Santamouris M. and D. Asimakopoulos (Eds). Passive cooling of buildings. pp.1-34.

Belarbi, R. 1998. Développement d'outils méthodologiques d'évaluation et d'intégration des systèmes évaporatifs pour le rafraîchissement passif des bâtiments. PhD Thesis of La Rochelle University (France).

Belarbi, R. and F. Allard. 2001. Development of two approaches for studying the behaviour of passive cooling systems in buildings. Renewable Energy. 22:507-524.

Bouvarel, I. and Y. Franck. 1994. Importances des coups de chaleur et des baisses de performances en été en aviculture. Sc. Et Tech. Avicoles. 8:710.

Dimoudi, A. 1997. Urban design. In : Santamouris, M., Asimakopoulos (Eds). Passive cooling of buildings. $1-34$.

Erens, P. J. 1988. Comparison of some design choices for evaporative cooler cores. Heat Transfer Eng. 9(2):29-35.

Ernst, R. A. 2008. Poultry Production in Hot Climates, 2nd Edition. Edited by N Daghir, American University of Beirut.

FAO, Middle East Poultry. 2004, Vol. 108 No. 184.

FISA. 2003. (Fédération Interprofessionnelle du Secteur Avicole). Pertes avicoles en été. L'ECONOMISTE. 1581:11.

Guedira A. 2001. La sécurité alimentaire au Maroc: quelle stratégie à l'aube du XXI siècle? Terre and Vie. 46/49:122.

Klein, S. A., W. A. Beckman J. W. Mitchel, J. A. Diuffie N. A. Duiffie and T. L. Freeman. 1998. TRNSYS manual. University of Wisconsin.

Salah, H. and M. Esmail, 2003. World poultry Vol. 19, No. 5.

Sbihi, A., A. Bentouhami, A. Benlekhal and S. Tazi. 2002. Elevage au Maroc : état des lieux et principales réalisations. Terre and Vie. 59/60:15. 